K A N D A I

\begin{tabular}{|l|l|l|}
\hline Volume 17 & No. 2, November 2021 & Halaman 280-296 \\
\hline
\end{tabular}

\title{
HARGA DIRI DAN STATUS SOSIAL: \\ MOTIF MERANTAU ORANG MINANGKABAU DALAM FILM \\ (Pride and Social Status: The Migrating Motive Minangkabau People in Cinema)
}

\author{
Herry Nur Hidayat, Bani Sudardi, Sahid Teguh Widodo, \& Sri K. Habsari \\ Sekolah Pascasarjana Universitas Sebelas Maret \\ Jalan Ir. Sutami 36A Surakarta, Jawa Tengah, Indonesia \\ Pos-el: herrynh@hum.unand.ac.id
}

(Diterima: 15 September 2020; Direvisi: 7 April 2021; Disetujui: 11 Juni 2021)

\begin{abstract}
Merantau has known as the Minangkabau ethnic identity. As a social behavior, merantau shows a change in concepts and motives. Technological developments, especially in transportation, are slowly shifting the concept of merantau to broaden its reach, followed by changes in motives. Merantau is no longer seen as a learning behavior and process, but is more economical, looking for a better life. This article explores and describes the merantau in the film with merantau from the Minangkabau community through a semiotic study. As a result, the change in the concept and motive for merantau in the film represents the merantau Minangkabau society. Through the movie characters, the motive for merantau, who seems to have an educational background in the film driveby personal motivation, namely self-esteem and social status, which in directly indicates economic motives.
\end{abstract}

Keywords: merantau, Minangkabau, film, representation

\begin{abstract}
Abstrak
Merantau telah dikenal sebagai identitas etnik Minangkabau. Sebagai sebuah perilaku sosial, merantau menunjukkan perubahan konsep dan motifnya. Perkembangan teknologi, terutama transportasi, secara perlahan menggeser konsep merantau menjadi meluas jangkauannya yang diiringi pula dengan perubahan motifnya. Merantau tidak lagi dipandang sebagai perilaku dan proses pembelajaran melainkan lebih bersifat ekonomis, yaitu mencari kehidupan yang lebih baik. Melalui kajian tekstual, artikel ini menggali dan menguraikan perilaku merantau yang ditampilkan dalam film dalam hubungannya dengan perilaku merantau masyarakat Minangkabau. Hasilnya, perubahan konsep dan motif merantau dalam film adalah bentuk representasi merantau masyarakat Minangkabau. Melalui tokoh-tokohnya, motif merantau yang tampaknya berlatar belakang pendidikan dalam film didorong oleh motivasi personal, yaitu harga diri dan status sosial yang secara tidak langsung menunjukkan motif ekonomis.
\end{abstract}

Kata-kata kunci: merantau, Minangkabau, film, representasi

DOI: $10.26499 / j k . v 17 i 2.2805$

How to cite: Hidayat, H. N., Sudardi, B., Widodo, S. T., \& Habsari, S. K. (2021). Harga diri dan status sosial: Motif merantau orang Minangkabau dalam film. Kandai, 17(2), 280-296 (DOI: 10.26499/jk.v17i2.2805)

PENDAHULUAN

Bagi orang Minangkabau, khususnya laki-laki, merantau sudah menjadi bagian dari kehidupan baik sosial maupun personal. Konsep pengertian merantau ini sebenarnya bukan hanya pergi meninggalkan nagari tetapi keluar dari rumah gadang sebagai wujud eksistensinya sebagai pemuda Minangkabau. Menurut Graves, merantau telah lama dikenal sebagai salah 
satu ciri khas budaya Minangkabau sebagai satu bentuk interaksi orang Minangkabau dengan dunia luar. Rantau dalam konteks ini berarti di mana saja di luar nagari tempat asalnya. Merantau merupakan sebuah petualangan pengalaman dan geografis (Graves, 2007). Anak laki-laki Minangkabau telah didorong meninggalkan rumah sejak usia muda. Remaja laki-laki Minangkabau tidak diberi akomodasi khusus dalam rumah gadang layaknya anak perempuan. Dia disuruh tidur di surau untuk belajar dan mempersiapkan diri menghadapi kehidupan (Kato, 1978; Naim, 2013).

$$
\text { Dalam perkembangannya, }
$$
pengertian rantau dan merantau di Minangkabau ini berhubungan dengan konsep wilayah geografis dan kultural. Wilayah yang didiami orang Minangkabau dikenal sebagai Luhak Nan Tigo yaitu Luhak Agam, Luhak Tanah Datar, dan Luhak Lima Puluh Kota. Ketiga wilayah luhak tersebut juga dikenal sebagai Alam Minangkabau. Sementara itu, wilayah di luar luhak tersebut oleh orang Minangkabau disebut rantau(Asnan, 2004; Murad, 1978; Navis, 1984; Wongso \& Idid, 2014). Akan tetapi, jika sebelumnya pengertian rantau terbatas pada wilayah kolonisasi di lembah sungai dan anak sungai yang mengalir ke timur dari Alam Minangkabau, kini rantau mengalami perluasan pengertian dan bermakna daerah di luar Minangkabau (Sumatera Barat). "Pergi merantau" diartikan meninggalkan rumah, orang tua, sanak saudara, dan kampung halaman, untuk sementara waktu maupun untuk selamalamanya. Sepanjang perjalanan sejarah Minangkabau merantau telah mendarah daging bagi penduduk Minangkabau (Graves, 2007). Rantau merupakan tempat berusaha, mencari ilmu dan pengalaman dan hasilnya untuk menambah kesejahteraan dan kebahagiaan diri sendiri, sanak saudara, dan kampung halaman. Merantau awalnya hanya terbatas pada wilayah geografis yaitu keluar dari batas wilayah luhak. Namun oleh karena perkembangan wilayah dan pesatnya kemajuan teknologi transportasi, wilayah merantau juga turut meluas (Mansoer et al., 1970; Murad, 1978, 1980). Bahkan kemunculan dan perkembangan dunia maya (internet) turut meluaskan makna perilaku merantau yang juga mencakup petualangan (orang Minangkabau) dalam dunia internet melalui world wide web (Franzia, 2017).

Bagi generasi muda Minangkabau kini, merantau dianggap sebagai sebuah kebiasaan orang Minangkabau dengan tujuan yang berbeda-beda. Perbedaan tujuan dan motif merantau serta tercapai atau tidaknya tujuan tersebut pada akhirnya mengakibatkan perbedaan pula dalam berperilaku di perantauan (Marta, 2014). Akan tetapi, tidak sedikit perantau asal Minangkabau (Sumatera Barat) yang pada akhirnya berpengaruh dan mempengaruhi perkembangan sosial, ekonomi, bahkan politik tanah perantauan (Bungo \& Hussin, 2011).

Seperti halnya kesusastraan Indonesia, sejarah perkembangan perfilman Indonesia tidak bisa dilepaskan dari muatan keminangkabauan. Muatan unsur-unsur Minangkabau sebagai sumber penciptaan film telah mewarnai perkembangan industri film di Indonesia. Pola perilaku merantau yang telah dianggap sebagai salah satu ciri identitas Minangkabau juga muncul dan ditampilkan dalam film, baik secara langsung maupun tidak.

Telah diketahui bahwa tidak sedikit film Indonesia diketahui mengandung muatan unsur-unsur keminangkabauan yang ditunjukkan melalui kajian. Harimau Tjampa dikenal sebagai film Indonesia pertama yang mengangkat unsur-unsur keminangkabauan (Kamal, 2013). Film Titian Serambut Dibelah 
Tujuh oleh Arief (2016) disebut memiliki muatan keminangkabauan yang berseberangan dengan falsafah masyarakat Minangkabau. Meskipun demikian, dia menganggap cerita film ini adalah bentuk autokritik penulis skenario atas penyimpangan keagamaan dan kebudayaan di Minangkabau. Muatan keminangkabauan dalam film Di Bawah Lindungan Ka'bah oleh Aisya, dkk. (2017) disebut menampilkan Minangkabau melalui unsur-unsur miseen scene dalam bentuk citraan visual (visual images), yaitu rumah gadang, baju kurung basiba, dan surau.

Inrasari (2015) menyebutkan film Tenggelamnya Kapal Van Der Wijck mengandung simbol-simbol keminangkabauan melalui penggunaan bahasa dan pakaian. Sementara itu melalui unsur mise en scene, Ophelia (2018) menemukan identitas budaya lokal Minangkabau dalam film ini berupa desain latar tempat dan waktu, kostum, serta dialog tokoh-tokohnya. Film yang sama oleh Trisnawati \& Yesicha (2018) dipandang mengandung representasi budaya matrilineal masyarakat Minangkabau yang sangat ketat yang hanya mengakui keturunan Minangkabau dari ibu bersuku Minangkabau. Mamak juga memiliki peran dan kedudukan yang sangat penting dalam sistem kekerabatan Minangkabau dalam film ini.

Film Surau dan Silek juga mengandung unsur keminangkabauan. Menurut Fitri (2018), film ini mengandung refleksi perbedaan persepsi terhadap silek (silat) dan surau. Di samping itu, digambarkan pula eratnya hubungan antara silek dan surau dengan nilai-nilai religius dan budaya masyarakat Minangkabau. Perbedaan persepsi terhadap silek dalam film ini tersebut dijelaskan oleh Arief (2018). Menurutnya, film ini menggambarkan perbedaan pandangan silek oleh generasi tua yang melihat silek sebagai sebuah produk surau berdasarkan filosofi dengan generasi muda yang melihat silek tidak lebih dari sekadar sebuah wadah untuk menonjolkan jati diri melalui berbagai kompetisi silat.

Muatan merantau yang tampil dalam Tabula Rasa menurut Tambunan (2017) adalah representasi salah satu pola migrasi masyarakat di Indonesia dari daerah pedesaan menuju perkotaan. Melalui tokoh-tokohnya, Mak dan Hans, merantau digambarkan sebagai usaha meraih kehidupan yang lebih baik di kota besar. Ditambahkan olehnya, dalam film ini kehidupan para perantau di perantauan tetap menunjukkan ciri dan identitas asal mereka.

Tampaknya, sebagai salah satu identitas Minangkabau, muatan merantau yang terdapat dalam film belum secara maksimal digali melalui beberapa kajian terhadap film sebelumnya. Jika mempertimbangkan bahwa film mampu merekonstruksi dan merepresentasikan kehidupan sehari-hari, bukan tidak mungkin perbedaan dan perubahan konsep maupun pengertian merantau yang terjadi juga muncul dalam film. Hal ini juga mempertimbangkan film sebagai sebuah produk sosial yang sekaligus menjadi bagian proses perubahan sosial. Apakah perluasan konsep merantau secara wilayah dan geografis juga tampil dalam film? Apakah motif merantau orang Minangkabau yang muncul dalam film terbatas pada aspek geografis, ekonomis, pendidikan, dan politis? Pertanyaan-pertanyaan tersebut muncul oleh karena dari sekian banyak film bermuatan keminangkabauan, ditemukan hanya satu judul film yang menyebut merantau secara langsung yaitu film Merantau (2009). Selain Merantau, film lain tidak secara langsung menggambarkan atau menyebut perilaku merantau dalam pengisahannya.

Merantau yang ditampilkan dalam film tidak hanya bisa dilihat dari konsep 
geografis, motif, maupun latar belakangnya. Aspek lain baik personal maupun sosial muncul dan mewujud menjadi aspek yang penting dalam memahami sebuah identitas etnik, terutama Minangkabau. Hal ini tentu saja berhubungan dengan pengertian identitas etnik yang tidak bisa lepas dari kedua aspek tersebut, personal dan sosial. Artikel ini membahas dan mendiskusikan pola perilaku merantau orang Minangkabau yang muncul dalam film. Pembahasan dan diskusi tidak hanya terbatas pada motif dan latar belakang merantau dilakukan, baik motif karena maupun motif untuk, tetapi juga bagaimana merantau berimplikasi menjadi ciri dan identitas Minangkabau muncul dalam film.

\section{LANDASAN TEORI}

Merantau telah dikenal sebagai salah satu ciri khas budaya Minangkabau. Satu bentuk interaksi orang Minangkabau dengan dunia luar adalah melalui merantau. Rantau dalam konteks ini berarti di mana saja di luar nagari tempat asalnya. Merantau merupakan sebuah petualangan pengalaman dan geografis (Graves, 2007).

Kato (1978) menyebut bahwa aktivitas merantau orang Minangkabau berhubungan dengan dinamika sosial Minangkabau yang menunjukkan sifat fleksibel dan konservatif. Selanjutnya, Kato (1989) juga menambahkan terdapat tiga konsep merantau orang Minangkabau. Yang pertama, merantau segmentasi kampung yaitu perpindahan untuk pembentuk satu pemukiman baru. Kedua, merantau dekat. Konsep merantau ini didorong oleh faktor luar daerah yang dianggap lebih memiliki peluang dalam hal ekonomi. Perantau dalam konsep ini masih memiliki hubungan erat dengan tanah kelahiran dengan wujud kerapnya berhubungan dengan warga kampung atau pulang untuk sekadar menjenguk kerabat. Ketiga, marantau cino. Dalam konsep meratau ini, perantau tidak lagi pulang ke kampung halaman dalam waktu yang lama. Akan tetapi, sejak berakhirnya Perang Dunia II perilaku merantau masyarakat Minangkabau lebih cenderung dilakukan oleh keluarga inti bukan individual. Hal ini menyebabkan para perantau meninggalkan kampung halamannya lebih lama bahkan tidak lagi kembali.

Merantau adalah tren kuno orang Minangkabau, wujud proses sosial yang berkelanjutan, dan secara fungsional terlibat dalam struktur sosial daerahdaerah di Indonesia. Tetapi seiring perjalanan waktu, tampak bahwa hubungan fungsional antara matrilineal Minangkabau dan merantau bersifat dinamis dan terus berkembang. Dalam hal jangkauan wilayah, Chadwick (1991) menyebutkan bahwa konsep merantau orang Minangkabau diketahui terdapat marantau dakek (merantau dekat) dan marantau jauah (merantau jauh di luar wilayah Sumatra Barat).

Tentang motif merantau, Naim (2013) menyimpulkan terdapat lima faktor sebab orang Minangkabau merantau. Pertama, faktor fisik yaitu ekologi dan lokasi. Menurut lokasinya, wilayah Minangkabau dianggap sebagai daerah terpencil yang jauh dari kegiatan perdagangan dan politik. Kedua, faktor ekonomi dan demografi. Dorongan ekonomi telah dianggap menjadi alasan paling kuat bagi orang Minangkabau untuk merantau. Hal ini berhubungan juga dengan kondisi alam yang sangat cocok untuk pertanian sementara hasilnya tidak lagi dianggap mencukupi kebutuhan. Ketiga, faktor pendidikan. Bisa dikatakan bahwa faktor ketiga ini terdapat pada golongan yang terbatas. Tidak semua masyarakat Minangkabau memiliki dorongan mencari atau melanjutkan pendidikan ke luar 
daerahnya. Keempat, daya tarik kota. Hampir semua kelompok masyarakat daerah tertarik dengan gambaran kehidupan kota. Tersedianya berbagai fasilitas baik ekonomi, pendidikan, hiburan, bahkan politik menjadi daya tarik tersendiri bagi orang Minangkabau untuk merantau. Kelima, keresahan politik. Faktor kelima ini hanya terbatas pada kurun waktu yaitu pada tahun 19261927 pada saat pemberontakan komunis. Puncaknya adalah pada 1958-1960 yaitu saat pemberontakan PRRI. Dalam kurun waktu tersebut, telah diakui belum pernah terjadi penduduk Minangkabau (Sumatera Barat) meninggalkan kampungnya dalam jumlah yang sangat besar.

Uraian singkat di atas menunjukkan adanya perubahan dalam hal pengertian dan konsep merantau dalam masyarakat Minangkabau sendiri. Konsep wilayah tujuan merantau menjadi meluas (menjauh) seiring perkembangan teknologi, terutama transportasi. Motif utama merantau sebagai proses pembelajaran (Navis, 1984) turut pula bergeser menjadi motif ekonomis. Pergeseran pengertian dan perubahan konsep merantau ini bukan tidak mungkin muncul pula dalam karya seni (sastra dan film) sebagai sebuah bentuk representasi identitas keminangkabauan.

Jika dicermati, antara film dengan budaya terjadi hubungan yang kompleks. Film adalah salah satu hasil seni yang menampilkan aspek budaya tertentu. Dalam hubungan antara film dan budaya, penting untuk diingat bahwa tidak hanya beragam, budaya juga selalu berubah dari satu periode ke periode berikutnya (Unnamed Author, 2016). Media, baik langsung maupun tidak, telah mempengaruhi pengetahuan dan wacana sosial. Seiring perkembangan media, audiens turut beradaptasi. Saat teknologi informasi berkembang, bentuk dan wujud media juga berubah dan turut mengubah pola kehidupan manusia baik secara individu maupun sosial (Gaines, 2010).

Dalam hubungannya dengan simbol, film adalah salah satu karya seni simbolik. Tokoh, latar, properti, suasana, peristiwa, dialog, akting pemeran, bahkan ilustrasi musik dalam film adalah simbol. Menurut Mudjiono (2011), dalam setiap bentuk cerita, sebuah simbol adalah sesuatu yang kongkret (sebuah obyek khusus, citra, pribadi, bunyi, kejadian atau tempat) yang mewakili atau melambangkan suatu yang kompleks, ide, sikap-sikap, atau rasa sehingga memperoleh arti yang lebih besar dari yang tersimpan dalam dirinya sendiri. Oleh karena itu sebuah simbol adalah suatu satuan komunikasi yang memiliki beban yang khusus sifatnya.

Oleh karena film dipandang sebagai proses sosiobudaya, tentunya ada kondisi, formula, dan material yang membentuknya. Perlu disadari juga bahwa di dalam proses sosial terdapat relasi kekuatan yang saling mempengaruhi. Kehidupan sosial adalah bentuk dialektika (konflik) kekuatan tersebut, penerimaan dan penentangan.

Perilaku dan praktik sosial serta material dan produk budaya selalu mengandung potensi pemaknaan. Dalam hal ini, potensi pemaknaan akan berhubungan dengan relasi antara sumber daya (teks) dengan dugaan makna yang telah dikenali (asumsi). Hodge \& Kress (1988) menyebut praktik ini sebagai model relasional (klasifikasi jenis/ragam pelaku sosial) dan model aksional (spesifikasi lakuan/aksi pelaku sosial).

\section{METODE PENELITIAN}

Material utama sebagai sumber data primer penelitian ini berupa tujuh film yang baik langsung maupun tidak mengandung unsur-unsur keminangkabauan terutama perilaku merantau. Ketujuh film tersebut adalah 
Harimau Tjampa (D. Djajakusuma, 1953), Para Perintis Kemerdekaan (Asrul Sani, 1977), Titian Serambut Dibelah Tujuh (Chaerul Umam, 1982), Merantau (Gareth Evans, 2009), Di Bawah Lindungan Ka'bah (Hanny R Saputra, 2011), Tenggelamnya Kapal Van Der Wijck (Sunil Soraya, 2013), dan Surau dan Silek (Arief Malin Mudo, 2017).

Muatan dan perilaku merantau yang menjadi fokus dalam kajian ini diperoleh melalui tindakan dan dialog tokoh yang ditemukan dalam analisis struktur naratif. Perilaku merantau dalam film tersebut kemudian dipandang sebagai sebuah representasi perilaku yang dilakukan oleh sebagian masyarakat Minangkabau. Selanjutnya, perilaku merantau dalam film tersebut dipandang sebagai sebuah representasi identitas etnik Minangkabau, baik sebagai produk sosial maupun sebagai proses sosial.

Dalam hal ini, pemaknaan sebuah film tidak hanya berdasarkan pada aspek narasi yang bersifat psikologis dan subjektif. Di sisi lain, film mengandung unsur-unsur yang bukan tidak mungkin adalah sistem kode tertentu yang hendak disampaikan kreator film. Dalam hal ini, kode (Stam et al., 1992) adalah sebuah sistem pembeda yang berkorespondensi secara tetap dan konstan dalam sebuah rangkaian pesan. Kode biasanya merujuk pada sebuah satuan konvensi yang sistematis serta pola pemilihan dan kombinasi unit-unit.

\section{PEMBAHASAN}

Sebuah cerita (film) dapat dikatakan sebagai representasi. Bercerita bukan hanya sekadar menyusun teks dan narasi, melainkan merangkai ide dan gagasan ekspresif melalui berbagai media. Halverson (2010) menyatakan bahwa terdapat hubungan tak terpisahkan antara cerita dengan identitas. Melalui berbagai bentuk media, sebuah kelompok masyarakat digambarkan sebagai melakukan, mendefinisikan, dan mengeksplorasi identitas mereka. Dalam hal ini, tidak terkecuali dengan film bermuatan keminangkabauan. Melalui visualisasi, film memamparkan ciri atau identitas Minangkabau melalui bentuk sebuah cerita. Melalui film, sebuah kelompok sosial baik sadar maupun tidak menyajikan representasi perilaku dan perubahan sosiobudayanya.

Sebagai sebuah perilaku yang dikenal sebagai ciri dan identitas Minangkabau, merantau tidak jarang ditampilkan dalam cerita film. Akan tetapi, pertimbangan bahwa film adalah representasi proses dan produk sosiobudaya membawa pada asumsi bahwa bukan tidak mungkin merantau dalam film mengandung simbol yang perlu dimaknai lebih lanjut.

Dalam Harimau Tjampa (1953), merantau ditampilkan melalui tokoh Lukman. Sepanjang cerita, tidak digambarkan asal usul tokoh ini. Lukman merantau ke nagari Pauah untuk berguru silek (silat) pada guru terbaik di sana. Saat meminta menjadi murid Datuk Langit, niatnya diurungkan karena syarat yang diminta adalah tiga ekor kerbau. Akhirnya, Lukman berguru silek pada Saleh, seorang guru di sebuah surau di daerah pinggiran Pauah.

Film Para Perintis Kemerdekaan (1977) yang diangkat dari novel karya Hamka, Di Bawah Lindungan Ka'bah, menampilkan merantau melalui tokoh Hamid. Melalui latar waktu masa perang kemerdekaan, film ini menampilkan merantau dengan latar belakang pendidikan. Tokoh Hamid meninggalkan Padang menuju Padangpanjang untuk melanjutkan pendidikannya dan membantu perjuangan perlawanan terhadap pemerintah Belanda. Keikutsertaannya dalam perlawanan inilah yang kemudian menyebabkan 
Hamid harus meninggalkan Indonesia menuju Makkah untuk menghindari penangkapan oleh pemerintah Belanda.

Film Titian Serambut Dibelah Tujuh (1982) dapat dikatakan tidak merepresentasikan secara khusus muatan keminangkabauan. Namun demikian, latar tempat yang disebutkan beberapa tokoh merujuk pada tempat dalam wilayah Sumatera Barat yaitu Batu Ampa, Tanjung Baringin, dan Koto Kaciak. Muatan merantau dalam film ini ditampilkan melalui tokoh Ibrahim. Ibrahim diceritakan mengemban amanat dari gurunya untuk mengajar agama Islam di kampung Tanjung Baringin. Di kampung inilah Ibrahim mengalami berbagai konflik dengan penduduk kampung. Secara tidak langsung, gambaran tokoh Ibrahim menunjukkan bahwa dia meninggalkan kampung halaman untuk menuntut ilmu. Oleh karena ilmu yang diperolehnya dianggap cukup oleh gurunya, Ibrahim dimintanya mengajar di tempat lain.

Sementara itu, merantau dalam film Merantau (2009) ditampilkan melalui tokoh Yuda. Yuda merantau ke Jakarta untuk mengajar silek, dengan kata lain mengamalkan ilmu yang dimilikinya. Seperti halnya Titian Serambut Dibelah Tujuh, film Merantau hanya sedikit mengandung muatan keminangkabauan. Namun demikian, film Merantau menampilkan berbagai peristiwa dan konflik sebagai gambaran proses belajar dalam merantau.

Film Di Bawah Lindungan Ka'bah (2011) adalah ekranisasi novel Hamka dengan judul yang sama. Meskipun terdapat perbedaan dengan novelnya, film ini mencoba untuk tetap setia dengan alur ceritanya. Muatan merantau dalam film ini ditampilkan melalui tokoh Hamid. Hamid diceritakan melanjutkan pendidikannya di Thawalib Padangpanjang dan kemudian mengajar di surau di kampungnya. Oleh karena status keluarga dan konfliknya dengan masyarakat kampungnya, Hamid tidak bisa meminang Zainab. Hal inilah yang kemudian menjadi alasan baginya untuk pergi merantau meninggalkan kampung halamannya hingga sampai ke Makkah.

Tenggelamnya Kapal van der Wijck (2013) menampilkan muatan merantau melalui Pendekar Sutan, Zainuddin, Muluk, dan Rusli. Diceritakan bahwa Pendekar Sutan pergi merantau hingga Makasar karena malu. Dia terus dihina kerabatnya oleh karena kemiskinan. Zainuddin adalah anak Pendekar Sutan yang menikah dengan seorang perempuan Makasar. Zainuddin memutuskan untuk kembali ke tanah kelahiran ayahnya di Batipuh. Pertemuan dan hubungannya dengan Hayati menimbulkan konflik dengan kerabat Hayati sehingga mengharuskannya pergi ke Padangpanjang. Merasa cintanya dikhianati dan harga dirinya direndahkan Hayati yang menikah dengan Azis, Zainuddin pergi meninggalkan ranah Minangkabau menuju Batavia bersama Muluk. Di Batavia, mereka berdua bertemu Rusli yang telah lebih dahulu merantau. Di sinilah Zainuddin menemukan kehidupannya. Dia berhasil menjadi seorang penulis terkenal di Surabaya. Meskipun tokoh Zainuddin bukan keturunan asli Minangkabau dan ditolak ninik mamak di Batipuh, tetapi pengakuannya terhadap tanah kelahiran ayahnya serta kehidupannya di Batipuh dan Padangpanjang cukup menjadi dasar tokoh ini berasal dari Minangkabau.

Meskipun hanya sekilas, Surau dan Silek (2017) menampilkan muatan merantau melalui tokoh Rustam, Irman, dan Johar Hakim. Tokoh Rustam sebelumnya tidak berniat merantau karena berniat mengajar anak-anak silek (silat) di kampungnya. Namun, karena malu melihat keberhasilan kawan-kawan sebayanya di rantau, Rustam memutuskan untuk merantau pula. 
Diketahui kemudian, Rustam merantau dan bekerja pada sebuah rumah makan di Yogyakarta. Tokoh Irman muncul dalam film ini sebagai contoh perantau berhasil yang bekerja di kedutaan besar di Inggris. Tokoh Johar Hakim juga digambarkan sebagai profil perantau yang berhasil. Tokoh ini adalah pensiunan dosen yang kemudian pulang ke kampung halamannya di Bukittinggi dari Yogyakarta untuk menghabiskan masa tuanya.

Secara umum telah diketahui, merantau oleh orang Minangkabau dimaknai meninggalkan kampung halaman tempat kelahiran. Naim (2013) menyebutkan bahwa merantau bagi masyarakat Minangkabau mengandung unsur pokok meninggalkan kampung halaman, dengan kemauan sendiri, untuk jangka waktu panjang atau pendek, dengan tujuan mencari penghidupan, menuntut ilmu atau mencari pengalaman, biasanya dengan maksud kembali pulang. Di sisil ain, merantau telah dianggap sebagai sebuah perilaku sosial yang membudaya. Dalam hal ini, sebagai salah satu bentuk migrasi, perilaku merantau tetap mempertahankan susunan sosial dan kultural tempat asalnya.

Tabel 1

Konsep dan Motif Merantau dalam Film

\begin{tabular}{|c|c|c|c|c|}
\hline No. & Film & Tokoh & Konsep merantau & Motif \\
\hline 1. & Harimau Tjampa & Lukman & marantau dakek & pendidikan \\
\hline 2. & $\begin{array}{l}\text { Para Perintis } \\
\text { Kemerdekaan }\end{array}$ & Hamid & $\begin{array}{l}\text { marantau dakek, marantau } \\
\text { jauah }\end{array}$ & pendidikan, pengalaman \\
\hline 3. & $\begin{array}{l}\text { Titian Serambut } \\
\text { Dibelah Tujuh }\end{array}$ & Ibrahim & marantau dakek & pendidikan, pengalaman \\
\hline 4. & Merantau & Yuda & marantau jauah & pendidikan, pengalaman \\
\hline 5. & $\begin{array}{l}\text { Di Bawah } \\
\text { Lindungan } \\
\text { Ka'bah }\end{array}$ & Hamid & $\begin{array}{l}\text { marantau dakek, marantau } \\
\text { jauah }\end{array}$ & pendidikan \\
\hline \multirow[t]{3}{*}{6.} & $\begin{array}{l}\text { Tenggelamnya } \\
\text { Kapal Van Der }\end{array}$ & Zainuddin & $\begin{array}{l}\text { marantau dakek, marantau } \\
\text { jauah }\end{array}$ & pendidikan, pengalaman \\
\hline & Wijck & Muluk & marantau jauah & pengalaman \\
\hline & & $\begin{array}{l}\text { Pandeka } \\
\text { Sutan }\end{array}$ & marantau jauah & pengalaman \\
\hline \multirow[t]{3}{*}{7.} & Surau dan Silek & Rustam & marantau jauah & pengalaman \\
\hline & & Johar & marantau jauah & pengalaman \\
\hline & & Irman & marantau jauah & pengalaman \\
\hline
\end{tabular}

Melalui deskripsi singkat film-film di atas, muatan merantau muncul dalam beragam wujud dan latar belakang, baik langsung maupun tidak. Seiring waktu rilis film, konsep dan motif merantau yang muncul dalam film tampaknya turut berubah. Sebagai sebuah bentuk representasi perilaku sosial, konsep merantau dalam film menunjukkan perbedaan baik sesuai latar cerita maupun waktu penciptaannya.

Dalam Harimau Tjampa, meskipun tidak diketahui asal kampung halamannya, tokoh Lukman menunjukkan perilaku merantau dalam konsep marantau dakek. Hal ini dibuktikan melalui kedatangannya di kampung Pauah dengan menumpang 
sebuah pedati. Indikator ini menunjukkan tempat yang tidak jauh dari kampung Pauah oleh karena jangkauan pedati yang terbatas. Maksud dan tujuannya merantau pun dapat dikategorikan sebagai tujuan merantau yang "klasik" yaitu untuk mendapatkan ilmu dan pengalaman, berguru silek.

Menariknya, dalam proses belajar ini ditampilkan pula proses pembelajaran dan pola perilaku kehidupan surau di Minangkabau. Selain mempelajari ilmu agama Islam dan silek, Harimau Tjampa juga menampilkan interaksi murid-murid surau dengan lingkungan masyarakat sekitar surau dan mengelola sawah "milik" surau sebagai bagian dari proses pembelajaran. Proses pembelajaran dalam surau ini juga muncul dalam film Para Perintis Kemerdekaan melalui tokoh Hamid yang tidak hanya terbatas belajar di surau Haji Wali. Tokoh Hamid juga diceritakan turut membantu Haji Wali menyelesaikan masalah adat dan keagamaan di wilayahnya. Di samping itu, Hamid dan kawan-kawannya juga mengelola sebuah penerbitan majalah sebagai bentuk amalan ilmu yang diperoleh sekaligus gerakan perlawanan terhadap pemerintah Belanda.

Perilaku merantau tokoh Hamid dapat disebut sebagai marantau dakek. Baik dalam Para Perintis Kemerdekaan maupun Di Bawah Lindungan Ka'bah tokoh Hamid merantau dalam lingkup Sumatera Barat, dari Padang ke Padangpanjang. Perbedaan tema cerita antara kedua film ini menyebabkan tampilan muatan merantau juga berbeda. Dalam Para Perintis Kemerdekaan, di Padangpanjang inilah Hamid mengembangkan pengetahuan dan wawasannya tentang nasionalisme, perjuangan, dan perlawanan terhadap kolonial Belanda. Sementara itu, dalam Di Bawah Lindungan Ka'bah, tokoh Hamid diceritakan melanjutkan pendidikannya di Thawalib
Padangpanjang dan kemudian mengajar di surau di kampungnya. Tokoh Hamid dalam kedua film tersebut juga secara tidak langsung menunjukkan konsep marantau jauah. Oleh karena konflik yang dialaminya, Hamid harus meninggalkan kampung merantau hingga ke Makkah.

Motif merantau yang agak berbeda ditampilkan dalam film Titian Serambut Dibelah Tujuh dan Merantau. Tokoh utama dalam kedua film ini memiliki niat bukan untuk menuntut ilmu melainkan mengamalkan ilmu yang dimiliki di rantau. Tokoh Yuda dalam film Merantau berniat mengajar silek di Jakarta. Sementara itu, Ibrahim, tokoh utama Titian Serambut Dibelah Tujuh, diceritakan mengemban amanat gurunya untuk mengajar agama Islam di kampung Tanjung Baringin. Dapat diduga bahwa sebelum Ibrahim mengemban tugas dari gurunya, dia telah menempuh ilmu sebelumnya. Hal ini dapat disandingkan dengan tokoh Yuda yang telah dianggap cukup menguasai silek sebelum berangkat merantau ke Jakarta. Dapat disimpulkan bahwa motivasi awal tokoh Ibrahim untuk merantau juga untuk menuntut ilmu. Di samping itu, dilihat dari konsep merantau, tokoh Ibrahim menggambarkan konsep marantau dakek, sedangkan Yuda menunjukkan konsep marantau jauah. Melalui tokoh Yuda ini, merantau digambarkan sebagai sebuah proses kehidupan sebagai wujud tanggung jawab laki-laki Minangkabau. Akan tetapi, melalui dialog ibu Yuda pada awal cerita juga tergambar bahwa merantau bukanlah sebuah kewajiban yang harus dijalani. Perwujudan tanggung jawab tersebut tidak harus dijalani melalui merantau.

Jika memperhatikan pengertian konsep marantau cino dilakukan oleh keluarga inti, perilaku merantau ini tidak ditemukan dalam film. Akan tetapi, jika memperhatikan pengertian marantau 
cino sebagai perilaku merantau yang tidak kembali ke kampung, beberapa film menunjukkan muatan tersebut. Perilaku marantau cino ini tampak pada tokoh Hamid dalam Di Bawah Lindungan Ka'bah dan Para Perintis Kemerdekaan, tokoh Zainuddin dalam Tenggelamnya Kapal van der Wijck serta tokoh Ibrahim dalam Titian Serambut Dibelah Tujuh. Hingga akhir cerita, Hamid tidak memiliki keinginan untuk kembali ke ranah Minangkabau oleh karena kekecewaannya terhadap Zainab hingga akhirnya Hamid pun meninggal di Makkah. Sementara itu, setelah kematian Hayati, Zainuddin pun tidak berniat kembali karena harga diri dan kekecewaannya tidak diterima oleh masyarakat Minangkabau di Batipuh. Demikian pula Ibrahim dalam Titian Serambut Dibelah Tujuh yang memutuskan untuk tetap tinggal di Tanjung Baringin. Akan tetapi, dapat dilihat bahwa konsep marantau cino ini tidak muncul sebagai motivasi awal tokoh pergi merantau. Perilaku ini tampil sebagai dampak konflik yang dialami tokoh yang menyebabkan tokoh tidak bisa pulang kembali ke kampung halamannya.

Hal ini berkebalikan dengan tokoh Johar Hakim dalam Surau dan Silek. Tokoh Johar Hakim digambarkan sebagai perantau sukses yang kembali ke kampung halaman di Bukittinggi untuk menghabiskan masa tuanya. Tokoh ini diceritakan telah merambah berbagai negara sebagai pengajar (dosen). Namun, karena kecintaan dan kerinduannya pada kampung halaman, dia kembali pulang setelah pensiun dari pekerjaannya. Dalam dialog dengan tokoh lain, Johar Hakin digambarkan sebagai marantau sabana marantau. Dalam film ini juga disebut oleh salah satu tokoh tentang marantau cino. Menurut tokoh Arman, marantau cino adalah marantau indak pulangpulang. Pernyataan ini seolah menunjukkan perilaku ini dilakukan baik keluarga inti maupun individu.

Di dalam film, perubahan dan perkembangan pola perilaku merantau ini ditunjukkan melalui motivasi pergerakan tokoh dan perubahannya sebagai pusat pengisahan. Perilaku merantau tokohtokoh dalam film adalah gambaran peristiwa yang benar-benar terjadi di masyarakat. Konsep marantau dakek, marantau jauah, dan marantau cino yang dikenal masyarakat Minangkabau muncul dalam film melalui tokohtokohnya. Begitu pula motif merantau dalam aspek pendidikan yang muncul dalam beberapa film.

Dalam hubungan dengan motif pendidikan dalam merantau, dorongan dan niat untuk menuntut ilmu ini mulai berkembang ketika sistem pendidikan formal dikenalkan oleh pemerintah kolonial Belanda pada sekitar awal abad 20. Akan tetapi, saat itu Belanda hanya menyediakan sekolah untuk keuntungan komersial dan administrasi saja. Di sisi lain, kesadaran akan pentingnya pendidikan mulai berkembang di tengah masyarakat Minangkabau (Murad, 1978). Beberapa penelitian menunjukkan bahwa pusat pendidikan di wilayah Sumatera Barat pada awal abad 20 adalah Padangpanjang dan Bukittinggi (Hadler, 2008; Murad, 1978; Naim, 2013). Oleh karena pemerintah kolonial Belanda tidak menyediakan fasilitas pendidikan yang memadai, maka didirikanlah lembaga pendidikan swasta (sekolah dan madrasah). Salah satu sekolah yang terkenal saat itu adalah Sekolah Thawalib (Naim, 2013). Gambaran kota Padangpanjang dan Bukittinggi sebagai pusat pendidikan di Sumatera Barat ini muncul dalam film Para Perintis Kemerdekaan, Di Bawah Lindungan Ka'bah, dan Tenggelamnya Kapal Van Der Wijck.

Merantau untuk mengamalkan ilmu, seperti yang ditampilkan dalam film 
Merantau dan Titian Serambut Dibelah Tujuh, juga dapat dirunut dari perkembangan perilaku merantau. Kesadaran akan pentingnya pendidikan bagi masyarakat Minangkabau mulai tumbuh sejak dikenalkannya sistem pendidikan formal oleh kolonial Belanda mengakibatkan kebutuhan akan pengajar atau guru yang juga meningkat. Dibuka dan didirikannya sekolah swasta dan madrasah membutuhkan guru yang tidak sedikit. Graves (dalam Murad, 1978) menyebutkan beberapa kampung menghimpun dana untuk mengirimkan anak muda mereka menuntut ilmu untuk menjadi seorang pengajar bahkan sampai ke Belanda. Murad menambahkan, mulai saat itulah aspek pendidikan menjadi latar belakang perilaku merantau masyarakat Minangkabau. Navis (Navis, 1984) menyebut perilaku sosial ini adalah efek "perlombaan" memajukan kaum kerabat dan nagari. Orang-orang tua berlombalomba menyekolahkan anaknya hingga perguruan tinggi. Menyekolahkan anakanak ke perguruan tinggi, selain untuk memperoleh rasa kebanggaan, dapat pula ditafsirkan sebagai mambangkik batang tarandam 'mengangkat kembali batang yang terendam'. Artinya, kaum kerabat mereka pada masa lalu juga adalah orang yang bermartabat sama dengan kerabat lain atau tidak kalah dengan kerabat yang lain.

Dalam praktiknya, tujuan mengirim pemuda menuntut ilmu untuk mengajar di kampungnya perlahan bergeser dan cenderung bersifat ekonomis. Sepertinya, konsep inilah yang lebih kuat menjadi latar belakang perilaku merantau bagi masyarakat Minangkabau. Bagi sebagian besar orang Minangkabau, merantau sama dengan mancari (mencari nafkah). Menurut Chadwick (1991) rantau adalah tampek pancarian (tempat pencarian) dalam arti memperoleh penghasilan untuk kehidupan yang lebih baik meskipun mereka sendiri sadar kehidupan di perantauan tidak jarang lebih susah dari hidup di kampung halaman.

Dalam hubungannya dengan pendidikan, terdapat anggapan semakin tinggi pendidikan maka akan semakin tinggi posisi atau jabatan pekerjaan sehingga akan memperoleh penghasilan yang tinggi pula. Oleh karena itu, banyak perantau dengan latar belakang menuntut pendidikan ini tidak pulang ke kampung melainkan tetap di perantauan untuk bekerja dan memperoleh penghasilan yang lebih layak. Hal ini muncul dalam Titian Serambut Dibelah Tujuh melalui tokoh Ibrahim. Terlepas dari muatan moral dan agama dalam struktur cerita, Ibrahim memutuskan untuk tinggal di Tanjung Baringin dengan pertimbangan kehidupan yang lebih baik karena dirinya telah diterima oleh penduduk kampung tersebut.

Idealnya, perantau dari Minangkabau akan pulang dan menetap di kampung halaman bila tiba masanya. Selain untuk melepaskan kerinduan, setidak-tidaknya untuk berkubur di tanah kelahiran dan disaksikan seluruh kerabat. Menurut Navis (1984) adalah suatu kehinaan bagi seluruh kaum apabila mereka membiarkan warganya mati dan berkubur di rantau. Ada dua aspek yang hendak mereka capai dalam hal ini, yakni: hati yang selalu terikat pada nagari asalusul nenek moyangnya. Alasan lain ialah karena sebab-sebab yang praktis, yaitu ada keluarga dekat yang akan merawat dan mengurus saat hari tua. Harapannya adalah mereka meninggal di hadapan kerabat dan dikuburkan di pusara kaum sendiri. Graves menyebut para perantau Minangkabau akan kernbali ke kampung halamannya dan tinggal menetap untuk selamanya setelah gelar atau predikat mereka naik (Graves, 2007). Dalam hal ini, Maude menyebutkan bahwa perantau Minangkabau yang kembali ke kampung halaman didominasi oleh pegawai negeri 
yang telah sampai masa pensiun (Maude, 1979). Hal ini muncul melalui tokoh Johar dalam Surau dan Silek. Tokoh ini digambarkan sebagai seorang pensiunan dosen yang kembali pulang ke kampung halaman menghabiskan masa tuanya.

Menurut Chadwick (1991), merantau sebelumnya mungkin bersifat sementara dan berlaku bagi sebagian besar laki-laki. Hal ini disebabkan kondisi di nagari mungkin sesuai dengan pandangan tertentu tentang masyarakat Minangkabau. Di luar situasi ini, bentuk merantau saat ini bukan tidak mungkin secara bertahap berkembang dalam hubungan yang terus berubah bersamaan dengan alasan personal dan munculnya bentuk organisasi sosial Minangkabau saat ini. Tampaknya, motif merantau yang digambarkan melalui tokoh-tokoh dalam film tidak sepenuhnya sama dengan pendapat Naim (2013) yang menyebut motif merantau orang Minangkabau adalah faktor geografis, ekonomis, pendidikan, dan politis.

Tokoh Lukman dalam Harimau Tjampa, pada awal cerita menunjukkan berguru dan belajar silek sebagai motivasinya merantau. Akan tetapi seiring bergulirnya cerita, dapat diketahui bahwa motivasi tokoh Lukman merantau adalah mencari pembunuh ayahnya dan membalas dendam kematiannya. Menyadari ayahnya seorang pendekar, Lukman telah memperhitungkan pembunuh ayahnya tentu seorang pendekar yang lebih hebat. Oleh karena itulah dapat diduga tokoh Lukman berniat merantau belajar silek untuk mengunggulinya sekaligus mencari dan membalas kematian ayahnya. Tampak bahwa terdapat motif lain di balik motifnya pergi merantau untuk berguru.

Baik dalam Para Perintis Kemerdekaan maupun Di Bawah Lindungan Ka'bah, jika diperhatikan lebih lanjut, tampak bahwa tujuan utama tokoh Hamid meninggalkan kampung halamannya menuju Padangpanjang bukanlah semata-mata untuk menuntut ilmu. Motivasi utama tokoh Hamid dalam Para Perintis Kemerdekaan meninggalkan Padang sebenarnya adalah menjauhkan diri dari Zainab. Dalam hal ini, Hamid sadar karena status keluarga dan keturunannya tidak sebanding dengan status keluarga Zainab. Demikian pula Hamid dalam Di Bawah Lindungan $K a$ 'bah. Motivasinya merantau hingga ke Makkah bukanlah semata-mata hendak berhaji, melainkan wujud pelariannya karena tidak bisa meminang Zainab. Hal ini ditampilkan melalui penggambaran kesedihannya berpisah dengan Zainab hingga saat kematian kedua tokoh ini. Hal serupa muncul dalam film Tenggelamnya Kapal Van Der Wijck. Alih-alih belajar dan menuntut ilmu, tokoh Zainuddin meninggalkan Batipuh menuju Padangpanjang untuk menghindari konflik dengan kerabat Hayati karena hubungan mereka tidak disetujui. Selain marantau dakek, tokoh Hamid dalam film Di Bawah Lindungan Ka'bah dan Para Perintis Kemerdekaan juga menggambarkan marantau jauah. Selain karena kekecewaannya tidak bisa mempersunting Zainab, Hamid memutuskan pergi ke Makkah untuk mewujudkan keinginannya berhaji (Di Bawah Lindungan Ka'bah) dan menghindari penangkapan oleh pemerintah kolonial Belanda (Para Perintis Kemerdekaan).

Tampaknya, dalam masyarakat Minangkabau sendiri terdapat perbedaan pandangan mengenai perilaku merantau ini. Gambaran tentang perbedaan pandangan tentang merantau ini muncul dalam film Merantau. Tokoh Yuda menganggap merantau adalah sebuah kewajiban laki-laki Minangkabau sebagai wujud tanggung jawabnya terhadap kerabat. Baginya, merantau adalah sebuah ujian pengalaman untuk diakui sebagai lelaki sejati (inisiasi). Di sisi lain, 
ibunya menganggap merantau bukanlah kewajiban untuk membuktikan diri sebagai lelaki. Melalui penggambaran tersebut dapat dikatakan bahwa perilaku merantau tidaklah selaludi pandang sebagai hal yang positif dan menguntungkan bagi sebagian masyarakat Minangkabau sendiri. Graves (2007) menyatakan, sejak masa pemerintahan kolonial Belanda, di nagari-nagari dengan lahan persawahan yang luas cenderung menolak perilaku merantau ini. Prasangka kelompok ini, terutama kaum penghulu yang menentang proses merantau ini, menonjol di daerah bersawah luas seperti di Agam, Tanah Datar, Solok, dan Lima Puluh Kota dan juga kalangan bangsawan di daerah pantai. Sikap ini nyata di kalangan penghulu dari daerah yang memiliki sawah paling luas di Tanah Datar. Tempat ini hampir tak seorang pun ingin merantau, kecuali keadaan benar-benar memaksa - jika ia betul-betul miskin total atau karena ia bermusuhan (berkonflik). Pandangan tokoh ibu Yuda dalam film Merantau tersebut seolah membenarkan pernyataan Graves tersebut. Keluarganya digambarkan memiliki kebun yang luas sebagai gambaran status dan kekayaannya. Sementara itu, dalam film Para Perintis Kemerdekaan, Di Bawah Lindungan Ka'bah, dan Tenggelamnya Kapal Van Der Wijck digambarkan adanya konflik personal tokoh utama (Hamid dan Zainuddin) dengan anggota masyarakat lain (kerabat Zainab dan kerabat Hayati) yang akhirnya menjadi motif utama merantau.

Tabel 2

Motivasi Tokoh Pergi Merantau dalam Film

\begin{tabular}{cllll}
\hline No. & \multicolumn{1}{c}{ Film } & \multicolumn{1}{c}{ Tokoh } & \multicolumn{1}{c}{ Motivasi } & \multicolumn{1}{c}{ Latar Belakang } \\
\hline 1. & Harimau Tjampa & Lukman & balas dendam & harga diri \\
2. & $\begin{array}{l}\text { Para Perintis } \\
\text { Kemerdekaan }\end{array}$ & Hamid & kekecewaan, pelarian & status, politik \\
3. & $\begin{array}{l}\text { Titian Serambut } \\
\text { Dibelah Tujuh }\end{array}$ & Ibrahim & kehidupan lebih baik & Ekonomi \\
4. & Merantau & Yuda & inisiasi & \\
5. & $\begin{array}{l}\text { Di Bawah Lindungan } \\
\text { Ka'bah }\end{array}$ & Hamid & kekecewaan & status sosial \\
6. & Tenggelamnya Kapal & Zainuddin & kekecewaan & status sosial \\
& Van Der Wijck & Muluk & kehidupan lebih baik & Ekonomi \\
& & Pandeka Sutan & harga diri & status sosial \\
7. & Surau dan Silek & Rustam & harga diri & status sosial \\
& & Johar & kehidupan lebih baik & ekonomi \\
& Irman & kehidupan lebih baik & ekonomi \\
\hline
\end{tabular}

Selain menggambarkan konsep marantau jauah, tokoh Rustam dalam film Surau dan Silek bisa disebut ekstrim dalam memandang perilaku merantau. Secara verbal dalam dialognya dengan ibunya, Rustam menyampaikan niatnya untuk merantau karena malu tidak memiliki pekerjaan dan penghasilan tetap di kampungnya. Meskipun pernyataan tersebut disangkal oleh ibunya, yang menyebut tidak ada niat merantau karena malu, tetapi pernyataan tokoh Rustam secara tidak langsung merupakan representasi salah satu anggapan terhadap 
merantau. Hal ini diperkuat melalui peristiwa pertemuannya dengan tokoh Irman, kawan sekolahnya, yang telah sukses di rantau. Dalam peristiwa itu, tergambar jelas rasa rendah diri Rustam terhadap kawan-kawannya yang telah sukses di rantau. Hal ini tampaknya sesuai dengan pendapat Navis (1984) yang menyatakan bahwa hidup tanpa pekerjaan, terutama di kampung halaman sendiri, dipandang tabu.

Perasaan malu tidak merantau yang digambarkan melalui tokoh Rustam ini tampaknya merupakan bentuk pergeseran anggapan dan pemaknaan yang keliru namun terjadi pada sebagian besar masyarakat Minangkabau. Seolah menjelaskan pernyataan Navis di atas, Graves menyatakan bahwa pemuda di daerah dengan persawahan yang luas dengan kehidupan yang menyenangkan enggan untuk merantau. Mereka tidak bekerja, menganggur, dan suka berkumpul untuk berjudi dan menyabung ayam. Di sisi lain, pemuda dari kelompok yang berbeda, dengan kekayaan terbatas, tampak lebih ambisius. Mereka merasa bosan karena dianggap sebagai anggota dari suku tertentu atau kemenakan orang tertentu. Di rantau, mereka merasa bebas membangun hidupnya secara mandiri tanpa melepaskan hubungannya dengan kerabat dan adatnya (Graves, 2007). Tampaknya, anggapan malu tidak merantau tumbuh dari satu kelompok pemuda yang tidak ingin disamakan dengan kelompok pemuda dengan perilaku yang negatif di kampung. Pemaknaan terhadap anggapan ini bergeser seiring waktu hingga pada satu titik tertentu menjadi pandangan negatif terhadap pemuda yang tidak merantau. Hal ini direpresentaikan melalui tokoh Rustam dalam film Surau dan Silek.

Sebagai sebuah representasi, film adalah gambaran kondisi dan peristiwa yang terjadi dalam kehidupan baik personal maupun sosial. Merantau yang telah dikenal sebagai salah satu identitas Minangkabau yang direpresentasikan dalam film, baik langsung maupun tidak menggambarkan perubahan dan perbedaan pandangan terhadap konsep dan motifnya. Tampak jelas perbedaan dan perubahan tersebut jika dilihat sesuai waktu rilis film.

Motif dan motivasi merantau yang muncul dalam film selalu berujung pada faktor ekonomi. Rasa malu dan kecewa selalu dihubungkan dengan status sosial keluarga dan kerabatnya. Secara tidak langsung faktor kekayaan keluarga menjadi salah satu sebab perilaku merantau ini. Meluasnya batasan wilayah dalam konsep merantau tidak lagi memandang merantau sebagai proses pembelajaran bagi laki-laki Minangkabau. Memperoleh pengetahuan dan pengalaman untuk kembali pulang bukan lagi dipandang sebagai merantau yang ideal. Representasi merantau di dalam film menunjukkan penyempitan makna menjadi hanya sebatas mancari, mencari nafkah dan kehidupan yang lebih baik terutama secara ekonomi dan finansial.

\section{PENUTUP}

Jika dihubungkan dengan pendapat Naim (2013) yang menyebut alasan merantau orang Minangkabau adalah geografis, ekonomis, pendidikan, dan politis, motif merantau yang muncul dalam film tidak sepenuhnya sama dengan pendapat tersebut. Harga diri dan malu tampak dominan sebagai alasan pergi merantau.

Namun demikian, jika kembali dirunut, motif tersebut tetap berujung pada aspek ekonomis dalam arti status sosial dan kekayaan keluarga. Kegagalan hubungan kekasih digambarkan oleh sebab perbedaan status sosial keluarga. Di samping atas nama kesukuan, penolakan atas pinangan terjadi juga oleh 
karena pertimbangan perbedaan tersebut. Anggapan yang keliru tentang tabu jika tinggal di kampung halaman tanpa memiliki pekerjaan tetap menjadi penguat alasan dan motif merantau tersebut. Faktor pendidikan yang muncul sebagai motif merantau juga tampak sebagai usaha untuk menaikkan status sosial keluarga. Secara tidak langsung aspek personal turut membangun pandangan sosial terhadap konsep dan motif merantau, begitu pula sebaliknya. Hal-hal tersebut tampak dominan muncul dalam film.

Terlepas dari berbagai motif merantau yang muncul dalam film tersebut, bagi masyarakat Minangkabau, merantau adalah sebuah proses pembelajaran dan pengalaman. Tumbuh dan berkembangnya pengertian marantau dakek, marantau jauah, serta marantau cino adalah wujud dinamika sosial yang tidak bisa dielakkan oleh sebuah kelompok masyarakat, dalam hal ini Minangkabau. Pergeseran pengertian dan ruang lingkup merantau tersebut terjadi oleh karena dinamika Minangkabau sebagai sebuah kelompok sosial yang anggota-anggotanya memiliki pemikiran yang dinamis pula dalam menyiasati perubahan sosial yang terjadi. Perubahan tatanan sosial baik regional, nasinal, maupun global, pada akhirnya turut mempengaruhi pola perilaku merantau ini.

\section{DAFTAR PUSTAKA}

Aisya, D. K., Yusril, Y., \& Sahrul, S. (2017). Kritik budaya Minangkabau dalam film Di Bawah Lindungan Ka'bah. Bercadik: Jurnal Pengkajian dan Penciptaan Seni, 4(2), 146. http://www.journal.isipadangpanjang.ac.id/index.php/B ercadik/article/view/569
Arief, M. (2016). Analisis konteks Islam dan budaya Minangkabau dalam skenario film Titian Serambut Dibelah Tujuh. Menara Ilmu, $X(2)$, 213-216. https://doi.org/10.33559/MI.V10I 73.66

Arief, M. (2018). Film Surau dan Silek (Ketika anak-anak menemukan sebuah makna) [Laporan Penelitian]. Surakarta.

Asnan, G. (2004). Geography, historiography and regional identity: West Sumatra in the 1950s. In H. Samuel \& H. S. Nordholt (Ed.), Indonesia In Transition: Rethinking "Civil Society", "Region", and "Crisis." Yogyakarta: Pustaka Pelajar.

Barthes, R. (1977). Image music text. London: Fontana Press.

Bungo, N., \& Hussin, N. (2011). Merantau ke Kuala Lumpur: Tradisi merantau dan berdagang masyarakat Minang. Geografia, 7(5).

Chadwick, R. J. (1991). Matrilineal inheritance and migration in a Minangkabau community. In Indonesia (Nomor 51). https://doi.org/10.1146/annurev.i mmunol.23.021704.115628

Fitri, D. (2018). Representasi ideologi Minangkabau dalam film Surau dan Silek ditinjau dari kajian semiotika. LAYAR: Jurnal Ilmiah Seni Media Rekam, 5(2), 66-77. https://jurnal.isbi.ac.id/index.php/ layar/article/view/795

Franzia, E. (2017). Cultural wisdom of Minangkabau ethnic community for local - global virtual identity. Mediterranean Journal of Social Sciences, 8(1), 325-329. https://doi.org/10.5901/mjss.2017 .v8n1p325 
Gaines, E. (2010). Media literacy and semiotics. New York: Palgrave Macmillan.

Graves, E. E. (2007). Asal-usul elite Minangkabau modern: Respons terhadap Kolonial Belanda abad $X I X / X X(\mathrm{~N}$. Andri, L. Marlina, \& Nurasni (ed.)). Jakarta: Yayasan Obor Indonesia.

Hadler, J. (2008). Sengketa tiada putus: Matriarkat, reformisme Agama, dan Kolonialisme di Minangkabau. Jakarta: Freedom Institute.

Halverson, E. R. (2010). Film as identity exploration: A multimodal analysis of youth-produced films. Teacher College Record, 112(9), 2352-2378.

Hodge, R., \& Kress, G. (1988). Social Semiotics. New York: Cornell University Press.

Inrasari, D. (2015). Representasi Nilai Budaya Minangkabau dalam Film "Tenggelamnya Kapal Van Der Wijck" (Analisis Semiotika Film) [Tesis S2, UIN Alauddin Makasar]. UIN Alauddin Makasar. http://repositori.uinalauddin.ac.id/1236/

Kamal, M. (2013). "Harimau Tjampa”; Film Berlatar Minangkabau Pertama. Kompasiana. https://www.kompasiana.com/alc hemist/552e1a116ea834ee3c8b45 6a/harimau-tjampa-film-berlatarminangkabau-pertama

Kato, T. (1978). Change and continuity in the Minangkabau matrilineal system. Indonesia, 25(25), 1-16. https://doi.org/10.2307/3350964

Kato, T. (1989). Nasab Ibu dan Merantau. Kuala Lumpur: Dewan Bahasa dan Pustaka Kementrian Pendidikan.
Mansoer, M. D., Imran, A., Sarwan, M., Idris, A. Z., \& Buchari, S. I. (1970). Sedjarah Minangkabau. Jakarta: Bhratara Djakarta.

Marta, S. (2014). Konstruksi makna budaya merantau di kalangan mahasiswa perantau. Jurnal Kajian Komunikasi, 2(1), 27-43. https://doi.org/10.24198/JKK.V2I 1.6048

Maude, A. (1979). How circular is Minangkabau migration? The Indonesian Journal of Geography, 9(37), 1-12.

Mudjiono, Y. (2011). Kajian semiotika dalam film. Jurnal Ilmu Komunikasi, 1(1), 125-138.

Murad, A. (1978). Merantau: Aspects of outmigration of the Minangkabau people [Thesis Master of Art]. Canberra: Australian National University.

Murad, A. (1980). Merantau: outmigration in a matrilineal society of West Sumatra. Indonesian population monograph series, 3. Canberra Australia Australian National Univ. Dept. of Demography.

Naim, M. (2013). Merantau pola migrasi suku Minangkabau. Yogyakarta: Gadjah Mada University Press.

Navis, A. A. (1984). Alam Terkembang Jadi Guru: Adat dan kebudayaan Minangkabau. Jakarta: Grafiti Press.

Ophelia, S. (2018). Analisis identitas budaya lokal Minangkabau melalui Mise-en-Scene dan dialog pada film "Tenggelamnya Kapal Van Der Wijck" [Tesis S2, Institut Seni Indonesia]. Yogyakarta: Institut Seni Indonesia. http://digilib.isi.ac.id/4252/

Stam, R., Burgoyne, R., \& FlittermanLewis, S. (1992). New vocabularies in film semiotics. London - New York: Routledge. 
Tambunan, S. M. G. (2017). Home as an emotional imagination and the ambiguity of space and taste in the urban culinary practices: A textual analysis of Tabula Rasa (2014). Seminar Nasional Budaya Urban, Kajian Budaya Urban di Indonesia dalam Perspektif Ilmu Sosial dan Humaniora: Tantangan dan Perubahan. Jakarta.

Trisnawati, T., \& Yesicha, C. (2018). Representasi budaya matrilineal Minangkabau dalam film Tenggelamnya Kapal Van Der Wijck. Jurnal Riset Komunikasi, l(2), 276-284. https://doi.org/10.24329/jurkom.v $1 \mathrm{i} 2.40$
Unnamed Author. (2016). Understanding media and culture: An introduction to mass communication. Minneapolis: University of Minnesota.

Wongso, J., \& Idid, S. Z. A. (2014). Characters of the historic cities in Minangkabau. Asset and facility management "Resilience and sustainability organizations.” 